\title{
Vitamin A equivalency and apparent absorption of $\beta$-carotene in ileostomy subjects using a dual-isotope dilution technique
}

\author{
Carolien A. Van Loo-Bouwman ${ }^{1}$, Ton H. J. Naber ${ }^{1,2}$, Richard B. van Breemen ${ }^{3}$, Dongwei Zhu ${ }^{3}$, \\ Heleen Dicke $^{4}$, Els Siebelink ${ }^{5}$, Paul J. M. Hulshof ${ }^{5}$, Frans G. M. Russel ${ }^{6}$, Gertjan Schaafsma ${ }^{5,7}$ \\ and Clive E. West ${ }^{1,5} \dagger$ \\ ${ }^{1}$ Department of Gastroenterology and Hepatology, Radboud University Nijmegen Medical Centre, PO Box 9101, \\ 6500 HB Nijmegen, The Netherlands \\ ${ }^{2}$ Department of Internal Medicine, Tergooi Hospitals, PO Box 10016, 1201 DA Hilversum, The Netherlands \\ ${ }^{3}$ Department of Medicinal Chemistry and Pharmacognosy, College of Pharmacy, University of Illinois, 833 S. Wood Street, \\ Chicago, IL 60612-7231, USA \\ ${ }^{4}$ Division of Dietetics, Radboud University Nijmegen Medical Centre, PO Box 9101, 6500 HB Nijmegen, The Netherlands \\ ${ }^{5}$ Division of Human Nutrition, Wageningen University, PO Box 8129, 6700 EV Wageningen, The Netherlands \\ ${ }^{6}$ Department of Pharmacology and Toxicology, Radboud University Nijmegen Medical Centre, PO Box 9101, 6500 HB Nijmegen, \\ The Netherlands \\ ${ }^{7}$ Research Group on Sports, Nutrition and Lifestyle, HAN University, PO Box 6960, 6503 GL Nijmegen, The Netherlands
}

(Received 2 June 2009 - Revised 8 December 2009 - Accepted 14 December 2009 - First published online 5 February 2010)

\begin{abstract}
The objective was to quantify the vitamin A equivalency of $\beta$-carotene in two diets using a dual-isotope dilution technique and the apparent $\beta$-carotene absorption as measured by the oral-faecal balance technique. Seventeen healthy adults with an ileostomy completed the 4-week dietcontrolled, cross-over intervention study. Each subject followed both diets for 2 weeks: a diet containing vegetables low in $\beta$-carotene content with supplemental $\beta$-carotene in salad dressing oil ('oil diet'; mean $\beta$-carotene intake $3 \cdot 1 \mathrm{mg} / \mathrm{d}$ ) and a diet containing vegetables and fruits high in $\beta$ carotene content ('mixed diet'; mean $\beta$-carotene intake $7.6 \mathrm{mg} / \mathrm{d}$ ). Daily each subject consumed a mean of $190 \mu \mathrm{g}\left[{ }^{13} \mathrm{C}_{10}\right] \beta$-carotene and $195 \mu \mathrm{g}$ $\left[{ }^{13} \mathrm{C}_{10}\right]$ retinyl palmitate in oil capsules. The vitamin A equivalency of $\beta$-carotene was calculated as the dose-corrected ratio of $\left[{ }^{13} \mathrm{C}_{5}\right]$ retinol to $\left[{ }^{13} \mathrm{C}_{10}\right]$ retinol in serum. Apparent absorption of $\beta$-carotene was determined with oral-faecal balance. Isotopic data quantified a vitamin $\mathrm{A}$ equivalency of $\left[{ }^{13} \mathrm{C}_{10}\right] \beta$-carotene in oil of 3.6:1 (95\% CI 2.8, 4.6) regardless of dietary matrices differences. The apparent absorption of (labelled and dietary) $\beta$-carotene from the 'oil diet' $(30 \%)$ was 1.9-fold higher than from the 'mixed diet' $(16 \%)$. This extrinsic labelling technique can measure precisely the vitamin A equivalency of $\beta$-carotene in oil capsules, but it does not represent the effect of different dietary matrices.
\end{abstract}

乃-Carotene: Vitamin A equivalency: Stable isotopes: Ileostomy subjects

The vitamin A equivalency of $\beta$-carotene is defined as the amount of $\beta$-carotene which is required in the diet to produce $1 \mu \mathrm{g}$ retinol in the body. According to the current views, $6 \mu \mathrm{g}^{(1,2)}$ or $12 \mu \mathrm{g}^{(3)}$ of $\beta$-carotene in a mixed diet are equivalent to $1 \mu \mathrm{g}$ dietary retinol. For supplemental $\beta$-carotene in oil, the current views are that $3.3 \mu \mathrm{g}^{(1,2)}$ or $2 \mu \mathrm{g}^{(3)}$ of $\beta$-carotene are equivalent to $1 \mu \mathrm{g}$ retinol.

Data concerning the vitamin A equivalency of $\beta$-carotene from various dietary sources are inconsistent. The way $\beta$-carotene is incorporated in dietary matrices (plant foods or dissolved in oil) influences the degree of absorption. Uptake into the enterocyte is the critical step in the bioconversion of $\beta$-carotene, since it is generally assumed that $2 \mu \mathrm{g}$ $\beta$-carotene in the enterocyte is equivalent to $1 \mu \mathrm{g}$ retinol in the body $^{(2,3)}$. In order to quantify how much $\beta$-carotene enters the enterocyte, stable-isotope techniques have been developed in the last decade ${ }^{(4,5)}$. However, these techniques and the studies in which they have been applied have reported conflicting results ${ }^{(6-9)}$.

Absorption studies performed with healthy subjects with an ileostomy have the advantage of excluding the possible effect of bacterial degradation or even synthesis in the large bowel of the nutrient under study, allowing accurate measurement of its apparent fractional absorption.

Unfortunately, absorption studies alone cannot quantify the vitamin A equivalency of $\beta$-carotene. Therefore in the present investigation, the extrinsic labelling technique and the classical oral-faecal balance technique were combined. In addition to the

\footnotetext{
Abbreviation: LC, liquid chromatography.

* Corresponding author: Dr Carolien A. Van Loo-Bouwman, fax + 31 318413577, email Carolien.VanLooBouwman@hotmail.com $\dagger$ Deceased.
} 
administered $\left[{ }^{13} \mathrm{C}_{10}\right]$ retinol, $\left[{ }^{13} \mathrm{C}_{5}\right]$ retinol, formed by central cleavage of administered $\left[{ }^{13} \mathrm{C}_{10}\right] \beta$-carotene, was measured in serum $^{(10,11)}$. The efficiency of absorption of retinol is generally expected to be over $90 \%$ in healthy subjects ${ }^{(2,3)}$.

The aim of the present $14 \mathrm{~d}$ cross-over diet-controlled study was to quantify the vitamin A equivalency of $\beta$-carotene and to measure the apparent $\beta$-carotene absorption in healthy adults with an ileostomy with an adequate vitamin A status. Subjects were given two types of controlled Western diets: an 'oil diet' which contained mainly supplemental $\beta$-carotene in oil as the source of $\beta$-carotene and a 'mixed diet' which contained mainly $\beta$-carotene from vegetables and fruits.

\section{Subjects and methods}

\section{Recruitment of subjects}

Subjects with an ileostomy aged 23-75 years from four hospitals in the surroundings of Nijmegen in The Netherlands were selected for participation. Their general health status was checked in their medical dossiers. The screening examination included a health and lifestyle questionnaire, a FFQ ${ }^{(12)}$, weight (precise to $0.1 \mathrm{~kg}$ ) and height measurement (precise to $0.5 \mathrm{~cm}$ ), and haematological analyses of blood, liver enzymes, creatinine, alkaline phosphatase and cholesterol. Exclusion criteria were as follows: routine clinical chemistry abnormalities, chronic diseases, ileal resection of $>15 \mathrm{~cm}$, medication suspected of interfering with fat-soluble-vitamin absorption, pregnancy, $\quad \mathrm{BMI}<18$ or $>30 \mathrm{~kg} / \mathrm{m}^{2}$, abnormal dietary pattern, excessive alcohol consumption $(>40 \mathrm{~g} / \mathrm{d})$, and consumption of carotenoids, vitamin, or mineral supplements 6 weeks before or during the study. A total of eighteen volunteers participated in the screening and were selected to form two groups, which were matched for sex, age, BMI and habitual energy intake. The present study was conducted according to the guidelines laid down in the Declaration of Helsinki and all procedures involving human subjects were approved by the Committee on Research Involving Human Subjects, Region Arnhem-Nijmegen, The Netherlands. Written informed consent was obtained from all subjects.

\section{Study design}

The study was designed as a cross-over intervention with two controlled diets in eighteen healthy ileostomy subjects. Each subject followed both diets for 2 weeks each. The subjects consumed capsules each day for 4 weeks during both diets. The capsules contained a mean of $190 \mu \mathrm{g} / \mathrm{d}\left[{ }^{13} \mathrm{C}_{10}\right] \beta$-carotene and $195 \mu \mathrm{g} / \mathrm{d}\left[{ }^{13} \mathrm{C}_{10}\right]$ retinyl palmitate in oil relative to their daily energy intake. The extrinsic dual-isotope-labelling technique is based on attaining a plateau of isotopic enrichment of $\beta$-carotene and retinol in serum during prolonged daily intake of capsules containing low doses of labelled $\beta$-carotene and labelled retinol ${ }^{(10,11)}$. The plateau has been reported to be reached by day $21^{(10,11)}$, and in preliminary investigations for the present study, it was shown that the plateau was reached by day 14 . On days $0,1,14,15,27$ and 28 fasting blood samples of $13 \mathrm{ml}$ were obtained, and then kept in the dark at $4^{\circ} \mathrm{C}$ for $30 \mathrm{~min}$ before being centrifuged at $3000 \mathrm{rpm}$ for $10 \mathrm{~min}$ at $4^{\circ} \mathrm{C}$ to separate cells from serum. Serum was stored at $-80^{\circ} \mathrm{C}$ until analysis. Fasting was defined as not consuming any food or energy-containing drinks for $12 \mathrm{~h}$ before the blood sampling. On days 13 and 14 and also on days 27 and 28 , complete $48 \mathrm{~h}$ ileostomy effluent (faeces) was collected at home, stored on dry ice in plastic containers, and then transported to the $-80^{\circ} \mathrm{C}$ freezer. The concentrations of carotenoids and retinol in duplicate diets, serum and in faeces were measured by HPLC, and the isotopic enrichments of serum and faecal retinol with $\left[{ }^{13} \mathrm{C}_{5}\right]$ retinol and $\left[{ }^{13} \mathrm{C}_{10}\right]$ retinol and of $\beta$-carotene with $\left[{ }^{13} \mathrm{C}_{10}\right] \beta$-carotene were measured by using liquid chromatography-MS (LC-MS).

\section{Diets and compliance}

One diet contained vegetables low in $\beta$-carotene content with supplemental $\beta$-carotene in salad dressing oil ('oil diet') and the other diet contained vegetables high in $\beta$-carotene content ('mixed diet'). The ratio of $\beta$-carotene provided by fruits to vegetables was 1 to 2.2 in the 'oil diet' and 1 to 8.4 in the 'mixed diet' as estimated from the Dutch food database ${ }^{(13)}$. Low- $\beta$-carotene fruits included a mix of orange, apple, kiwi and banana. Menus were designed for ten levels of energy intake ranging from 7 to $16 \mathrm{MJ} / \mathrm{d}$. The subjects were allocated to an energy intake level close to their habitual energy intake, which was estimated from a FFQ ${ }^{(12)}$. Both diets were designed according to the Dutch guidelines for a healthy diet ${ }^{(14)}$ and provided $90 \%$ of energy intake. All food was weighed out for each subject. The remaining $10 \%$ of energy had to be chosen from a list of low-fat food items, which did not contain carotenoids or retinol, and which had to be recorded in a diary. The diaries were inspected twice weekly. Body weight was recorded twice weekly and energy intake was adjusted, when necessary, to limit changes in weight to less than $2 \mathrm{~kg}$. The food had to be reheated in a microwave oven at home. With each hot meal, a salad with salad dressing was provided. The salad dressing for the 'oil diet' was supplemented with synthetic $\beta$-carotene (all-trans $\beta$-carotene, $30 \%$ suspension in vegetable oil; Hoffmann-La Roche, Basle, Switzerland). The margarine (Unilever, Rotterdam, The Netherlands) was not supplemented with retinol or $\beta$-carotene. Subjects kept a diary for monitoring compliance to the diet, to the intake of the capsules, to fasting instructions, and to ileostomy effluent collection. In the diary, illnesses, medication and the daily choice of low-fat food items had to be recorded.

Diets were homogenised, extracted and analysed in duplicate by HPLC as described previously ${ }^{(11)}$.

\section{Chemical analysis of retinol and carotenoids in serum and in faeces}

Retinol and carotenoids in serum were analysed using the HPLC method with absorbance detection as described previously ${ }^{(11)}$. Within- and between-run $\mathrm{CV}$ for the quantitative analysis of retinol in serum were 1.1 and $3.8 \%$ and were 6.1 and $9.2 \%$ for the quantitative analysis of $\beta$-carotene.

Ileostomy effluent of $48 \mathrm{~h}$ from each subject were pooled, homogenised and weighed. Sample preparation was carried out in duplicate and has been described previously ${ }^{(11)}$. The recovery of $\beta$-carotene was $86(\mathrm{SD} 6) \%(n 3)$ which was measured by spiking faeces samples with $\beta$-carotene. 
Within- and between-run $\mathrm{CV}$ for the chemical analysis of $\beta$-carotene in faeces were 3.9 and $6.2 \%$.

\section{Capsule administration and measurement of isotopic enrichment in serum and in faeces}

Three capsules were prepared to meet the proportion of labelled compounds to the daily level of energy intake. The capsules contained $65 \cdot 1,82 \cdot 8$ or $98 \cdot 0 \mu \mathrm{g}\left[12,13,14,15,20,12^{\prime}\right.$, $\left.13^{\prime}, 14^{\prime}, 15^{\prime}, 20^{\prime}{ }^{13} \mathrm{C}_{10}\right] \beta$-carotene and $61 \cdot 7,83 \cdot 2$ or $102 \cdot 1 \mu \mathrm{g}$ $\left[8,9,10,11,12,13,14,15,19,20-{ }^{13} \mathrm{C}_{10}\right]$ retinyl palmitate in oil (analysed values). The preparation of the capsules and $\beta$-carotene analyses were performed as described previously ${ }^{(11)}$. The $\left[{ }^{13} \mathrm{C}_{10}\right] \beta$-carotene and $\left[{ }^{13} \mathrm{C}_{10}\right]$ retinyl palmitate were synthesised at ARC Laboratories (Apeldoorn, The Netherlands) as described previously ${ }^{(15)}$. The ratios of unlabelled retinol, $\left[{ }^{13} \mathrm{C}_{5}\right]$ retinol, $\left[{ }^{13} \mathrm{C}_{10}\right]$ retinol, unlabelled $\beta$-carotene and $\left[{ }^{13} \mathrm{C}_{10}\right] \beta$-carotene in serum and in faeces were measured using LC-atmosphere pressure chemical ionisation-MS assay $(\mathrm{LC}-\mathrm{APCI}-\mathrm{MS})^{(16,17)}$. $\beta$-Carotene and $\left[{ }^{13} \mathrm{C}_{10}\right] \beta$-carotene were monitored in negative ion mode at $\mathrm{m} / \mathrm{z}, 536$ and $\mathrm{m} / \mathrm{z}, 546$, respectively ${ }^{(17)}$. Retinol, $\left[{ }^{13} \mathrm{C}_{5}\right]$ retinol and $\left[{ }^{13} \mathrm{C}_{10}\right]$ retinol were measured as $\left[\mathrm{MH}-\mathrm{H}_{2} \mathrm{O}\right]^{+}$ions in positive ion mode at $\mathrm{m} / z, 269$, $\mathrm{m} / \mathrm{z}, 274$ and $\mathrm{m} / \mathrm{z}, 279$, respectively ${ }^{(17,18)}$.

\section{Calculations}

The isotopic enrichment levels of $\beta$-carotene were calculated as the signal measured by LC-MS at $\mathrm{m} / \mathrm{z} 546$ divided by the total signal at $\mathrm{m} / \mathrm{z} 536$ and 546. The isotopic enrichment levels of retinol were calculated as the signal at $\mathrm{m} / \mathrm{z} 274$ (or 279) divided by the total signal at $\mathrm{m} / \mathrm{z}, 269,274$ and 279. The vitamin A equivalency of $\beta$-carotene in oil relative to that of retinol in oil was calculated for each subject as the inverse ratio of the dose-corrected ratio of $\left[{ }^{13} \mathrm{C}_{5}\right]$ retinol to $\left[{ }^{13} \mathrm{C}_{10}\right]$ retinol in serum (by wt as compared with $1 \mu \mathrm{g}$ retinol) as follows ${ }^{(19)}$ :

$1 /\left(\right.$ Enrichment of retinol in serum with $\left[{ }^{13} \mathrm{C}_{5}\right] \mathrm{retinol} /$ enrichment of retinol in serum with $\left[{ }^{13} \mathrm{C}_{10}\right]$ retinol)

$\times\left(\right.$ dose of $\left[{ }^{13} \mathrm{C}_{10}\right]$ retinol/dose of $\left[{ }^{13} \mathrm{C}_{10}\right] \beta-$ carotene $)$.

For each diet, the apparent absorption (\%) of total $\beta$-carotene (both labelled and unlabelled) was calculated for each subject by subtracting the amount of $\beta$-carotene in faeces $(48 \mathrm{~h})$ from the amount consumed $(48 \mathrm{~h})$ and dividing the difference by the amount consumed multiplied by 100 . A necessary condition to use this calculation is to standardise strictly the daily nutrient intake during the 2 -week intervention study.

Table 1. Characteristics of the seventeen ileostomy subjects at baseline*

(Mean values and standard deviations)

\begin{tabular}{|c|c|c|c|c|c|c|}
\hline & \multicolumn{2}{|c|}{ Group 1 ( $n 9)$} & \multicolumn{2}{|c|}{ Group 2 (n 8) } & \multicolumn{2}{|c|}{ Laboratory references } \\
\hline & Mean & SD & Mean & SD & Male & Female \\
\hline \multicolumn{7}{|l|}{$\operatorname{Sex}(n)$} \\
\hline Male & \multicolumn{2}{|c|}{3} & \multicolumn{2}{|c|}{2} & & \\
\hline Female & \multicolumn{2}{|c|}{6} & \multicolumn{2}{|c|}{6} & & \\
\hline Age (years) & $47 \cdot 1$ & $12 \cdot 2$ & 51.5 & 13.9 & & \\
\hline BMI $\left(\mathrm{kg} / \mathrm{m}^{2}\right)$ & $26 \cdot 0$ & 2.9 & $26 \cdot 0$ & $2 \cdot 1$ & & \\
\hline Habitual energy intake (MJ) & 8.9 & 1.2 & $9 \cdot 8$ & 1.6 & & \\
\hline \multicolumn{7}{|l|}{ Smoking $(n)$} \\
\hline Never & \multicolumn{2}{|c|}{3} & \multicolumn{2}{|c|}{2} & & \\
\hline Yes & \multicolumn{2}{|c|}{0} & \multicolumn{2}{|c|}{3} & & \\
\hline Stopped & \multicolumn{2}{|c|}{6} & \multicolumn{2}{|c|}{3} & & \\
\hline \multicolumn{7}{|l|}{ Alcohol } \\
\hline Never $(n)$ & \multirow{2}{*}{\multicolumn{2}{|c|}{$\begin{array}{l}1 \\
8\end{array}$}} & \multicolumn{2}{|c|}{3} & & \\
\hline Yes $(n)$ & & 8 & \multicolumn{2}{|c|}{5} & & \\
\hline Consumption (glasses per week) & 5 & - & 8 & - & & \\
\hline \multicolumn{7}{|l|}{ Medication $(n)$} \\
\hline No & \multicolumn{2}{|c|}{2} & \multicolumn{2}{|c|}{1} & & \\
\hline Yes & \multicolumn{2}{|c|}{7} & \multicolumn{2}{|c|}{7} & & \\
\hline \multicolumn{7}{|l|}{ Diagnosed disease $(n)$} \\
\hline Crohn's disease & \multicolumn{2}{|c|}{3} & \multicolumn{2}{|c|}{5} & & \\
\hline Ulcerative colitis & \multicolumn{2}{|c|}{1} & \multicolumn{2}{|c|}{2} & & \\
\hline Various & & & & & & \\
\hline $\mathrm{Hb}(\mathrm{g} / \mathrm{l})$ & 142 & 18 & 135 & 10 & $131-172$ & $118-156$ \\
\hline Packed cell volume (litres/litres) & 0.42 & 0.05 & 0.42 & 0.03 & $0.39-0.51$ & $0.34-0.46$ \\
\hline Erythrocytes (cells $\times 10^{12} / \mathrm{l}$ ) & $4 \cdot 7$ & 0.7 & $4 \cdot 7$ & 0.6 & $4 \cdot 4-5 \cdot 6$ & $3 \cdot 7-5 \cdot 2$ \\
\hline Leucocytes (cells $\left.\times 10^{9} / \mathrm{l}\right)$ & $7 \cdot 5$ & $1 \cdot 1$ & 6.9 & $1 \cdot 2$ & $4 \cdot 0-10 \cdot 0$ & - \\
\hline Thrombocytes (cells $\times 10^{9} / \mathrm{l}$ ) & 274 & 58 & 284 & 54 & $120-350$ & - \\
\hline Creatinine $(\mu \mathrm{mol} / \mathrm{l})$ & 80 & 14 & 80 & 13 & $60-110$ & $50-90$ \\
\hline Alanine aminotransferase (IU/I) & 34 & 13 & 22 & 9 & $<45$ & - \\
\hline Alkaline phosphatase $(\mathrm{U} / \mathrm{l})$ & 82 & 22 & 74 & 25 & $<120$ & - \\
\hline Cholesterol $(\mathrm{mmol} / \mathrm{l})$ & $5 \cdot 3$ & 0.8 & 4.5 & 0.8 & $<6.5$ & - \\
\hline
\end{tabular}

* Groups 1 and 2 were matched for sex, age, BMI and habitual energy intake. There were no differences between the groups (two-tailed $t$ tests for independent samples). Medication that is suspected of interfering with fat-soluble-vitamin absorption was not allowed and not used. 


\section{Design and statistical analysis}

A cross-over design was chosen to eliminate between-subject variation. A carry-over effect was unlikely, because in preliminary investigations, it was shown that isotopic enrichment levels were under the detection limit after $7 \mathrm{~d}$ after intervention. Based on previous data ${ }^{(11)}$, a sample size of seventeen subjects had a $80 \%$ power to detect a difference in vitamin A equivalency between treatments of 0.27 with a significance level $(\alpha)$ of 0.05 (two-sided). Data are shown as means and $95 \% \mathrm{CI}$ or standard deviations (in the case of descriptive measures). Data of serum concentrations and enrichments were averaged for days 0 and 1, for days 14 and 15, and for days 27 and 28 for each subject. To evaluate differences in baseline blood values between the two groups, $t$ tests for independent samples were performed. ANOVA was used to test order effects. Because the order of the two diets did not significantly contribute to the model $(P=0 \cdot 23)$, serum retinol and serum $\beta$-carotene concentrations at baseline and after each diet were compared between the two dietary treatments with a paired $t$ test. To test whether the percentages of apparent absorption were significantly different between both diets, paired $t$ tests were performed. All tests were twosided, and $P$ values $<0.05$ were considered significant. The computer package SPSS 12.0 (SPSS Inc., Chicago, IL, USA) and Microsoft Office Excel 2003 (Microsoft Corp., Redmond, WA, USA) were used for all statistical calculations and data handling.

\section{Results}

The baseline characteristics of the seventeen subjects who completed the study are shown in Table 1. One individual dropped out because of not following the diet. No significant differences were observed between both groups with respect to haematological analyses of blood, liver enzymes, creatinine, alkaline phosphatase and cholesterol. The reported compliance to the diets was very good: $99.4 \%$ of the capsules and $97 \%$ of the diet. Inspection of the diaries did not reveal any deviations from the protocol, which could have affected the results.

The daily energy and nutrient contents of the diets are given in Table 2 , and the dietary sources of $\beta$-carotene in the diets are divided into the salad dressing oil and the vegetables and fruits. Table 3 shows the serum concentrations of retinol and provitamin A carotenoids of the subjects during the study. There were no significant differences between the groups in terms of serum retinol and serum $\beta$-carotene concentrations after each diet period compared with baseline. No significant post-intervention inter-diet differences for either retinol or $\beta$-carotene concentrations in serum were found.

The isotopic enrichments of retinol and $\beta$-carotene in serum are shown in Table 4. For each subject, the vitamin A equivalency of $\left[{ }^{13} \mathrm{C}_{10}\right] \beta$-carotene in oil was calculated. The mean vitamin A equivalency of $\left[{ }^{13} \mathrm{C}_{10}\right] \beta$-carotene in oil was $3.71(95 \%$ CI $2.79,4.63) \mu \mathrm{g}(\mathrm{CV} 49 \%)$ in response to the 'oil diet' and 3.56 (95\% CI 2.86, 4.26) $\mu \mathrm{g}(\mathrm{CV} 40 \%)$ in response to the 'mixed diet'.

Oral-faecal balance data demonstrate an apparent fractional absorption of $\beta$-carotene of 1.9-fold higher from
Table 2. Total daily intake of energy, macronutrients, fibres, retinol and provitamin A carotenoids of two controlled diets during the 4-week cross-over intervention study*

\begin{tabular}{lcc}
\hline & Oil diet & Mixed diet \\
\hline Energy (MJ) & $9 \cdot 5$ & $9 \cdot 9$ \\
Fat $(\mathrm{g})$ & 72 & 78 \\
Protein $(\mathrm{g})$ & 80 & 81 \\
Carbohydrates $(\mathrm{g})$ & 304 & 292 \\
Fibres $(\mathrm{g})$ & 26 & 29 \\
Alcohol $(\mathrm{g})$ & 9 & 8 \\
Retinol $(\mu \mathrm{g})$ & 192 & 180 \\
Total $\beta$-carotene in salad dressing oil $(\mu \mathrm{g})$ & 2647 & $<1$ \\
Total $\beta$-carotene in vegetables and fruits $(\mu \mathrm{g})$ & 427 & 7635 \\
trans- $\beta$-Carotene $(\mu \mathrm{g})$ & 3007 & 6859 \\
cis- $\beta$-Carotene $(\mu \mathrm{g})$ & 67 & 776 \\
$\alpha-$ Carotene $(\mu \mathrm{g})$ & 49 & 1121 \\
$\beta$-Cryptoxanthin $(\mu \mathrm{g})$ & 180 & 115 \\
\hline
\end{tabular}

${ }^{*}$ Results are based on the analysis of typical $11 \mathrm{MJ}$ duplicate diets and the calculated composition ${ }^{(13)}$ of the consumed free items, which did not contain carotenoids or retinol.

the 'oil diet' (30\%) than from the 'mixed diet'(16\%) (Table 5). With the oral-faecal balance data and the generally assumed bioconversion of $50 \%$ for absorbed $\beta$-carotene ${ }^{(2,3)}$, the vitamin A equivalency of the unlabelled $\beta$-carotene was estimated as $6 \cdot 7: 1(1 /(0.30 \times 0.5))$ for the 'oil diet' and as $12 \cdot 5: 1(1 /(0 \cdot 16 \times 0 \cdot 5))$ for the 'mixed diet'. Neither labelled retinol nor unlabelled retinol was detected in faeces.

\section{Discussion}

Vitamin A equivalency of $\left[{ }^{13} C_{10}\right] \beta$-carotene in oil using data obtained with a dual-isotope dilution technique

Our data in these healthy adults with an ileostomy show that the average vitamin A equivalency of extrinsic labelled $\beta$-carotene in oil is $3 \cdot 6: 1$ regardless of dietary matrices differences. This finding is consistent with the vitamin A equivalency of $\beta$-carotene of $3 \cdot 3: 1$ of $\mathrm{FAO} / \mathrm{WHO}^{(1,2)}$. The vitamin $\mathrm{A}$ equivalencies of $\beta$-carotene were similar for both diets, mainly because the enrichment of retinol in serum with $\left[{ }^{13} \mathrm{C}_{5}\right]$ retinol and with $\left[{ }^{13} \mathrm{C}_{10}\right]$ retinol were similar for both diets (Table 4). It appears that labelled $\beta$-carotene

Table 3. Serum concentrations $(\mu \mathrm{mol} / \mathrm{l})$ of retinol and provitamin $A$ carotenoids of two consecutive days of collecting fasting blood samples at baseline and after 2 weeks of controlled diets*

(Mean values and standard deviations)

\begin{tabular}{|c|c|c|c|c|c|c|}
\hline & \multicolumn{2}{|c|}{$\begin{array}{l}\text { Baseline } \\
(n 17)\end{array}$} & \multicolumn{2}{|c|}{$\begin{array}{l}\text { After 'oil diet' } \\
\quad(n 17)\end{array}$} & \multicolumn{2}{|c|}{$\begin{array}{c}\text { After 'mixed } \\
\text { diet' }(n 17)\end{array}$} \\
\hline & Mean & SD & Mean & SD & Mean & SD \\
\hline Retinol & $2 \cdot 18$ & 0.45 & $2 \cdot 00$ & 0.43 & 1.92 & 0.47 \\
\hline Total $\beta$-carotene & 0.26 & 0.16 & 0.44 & 0.31 & 0.33 & 0.16 \\
\hline trans- $\beta$-Carotene & 0.24 & 0.31 & 0.42 & 0.31 & 0.31 & 0.16 \\
\hline cis- $\beta$-Carotene & 0.02 & 0.01 & 0.02 & 0.01 & 0.02 & 0.01 \\
\hline$\alpha$-Carotene & 0.03 & 0.03 & 0.03 & 0.02 & 0.04 & 0.03 \\
\hline$\beta$-Cryptoxanthin & 0.12 & 0.08 & 0.09 & 0.04 & 0.09 & 0.04 \\
\hline
\end{tabular}

* There were no differences between the groups at baseline, after the 'oil diet', and after the 'mixed diet' and no differences between the measurement time points (paired $t$ tests). Group 1 ( $n$ 9) followed for 2 weeks the 'oil diet' diet and consecutively for 2 weeks the 'mixed diet' and group $2(n 8)$ followed for 2 weeks the 'mixed diet' and consecutively for 2 weeks the 'oil diet'. 
Table 4. Vitamin A equivalency of $\left[{ }^{13} \mathrm{C}_{10}\right] \beta$-carotene in oil after 2 weeks of controlled diets* (Mean values and $95 \%$ confidence intervals)

\begin{tabular}{|c|c|c|c|c|c|}
\hline \multirow[b]{2}{*}{ Symbol } & \multirow[b]{2}{*}{ Description } & \multicolumn{2}{|c|}{ Oil diet $(n 17)$} & \multicolumn{2}{|c|}{ Mixed diet $(n 17)$} \\
\hline & & Mean & $95 \% \mathrm{Cl}$ & Mean & $95 \% \mathrm{Cl}$ \\
\hline$E_{5, s R}$ & Enrichment of retinol in serum with $\left[{ }^{13} \mathrm{C}_{5}\right]$ retinol & 0.00635 & $0.00520,0.00750$ & 0.00653 & $0.00507,0.00799$ \\
\hline $\mathrm{E}_{10, \mathrm{sR}}$ & Enrichment of retinol in serum with $\left[{ }^{13} \mathrm{C}_{10}\right]$ retinol & 0.01551 & $0.01172,0.01930$ & 0.01475 & $0.01242,0.01708$ \\
\hline $\mathrm{E}_{10, \mathrm{sC}}$ & Enrichment of $\beta$-carotene in serum with $\left[{ }^{13} \mathrm{C}_{10}\right] \beta$-carotene & 0.04153 & $0.03672,0.04633$ & 0.04902 & $0.04211,0.05593$ \\
\hline \multirow[t]{3}{*}{$\begin{array}{l}E_{10, f C} \\
A_{R, \text { cap }}\end{array}$} & $\begin{array}{l}\text { Enrichment of } \beta \text {-carotene in faeces with }\left[{ }^{13} \mathrm{C}_{10}\right] \beta \text {-carotene } \\
\text { Dose }(\mu \mathrm{mol} / \mathrm{d}) \text { of }\left[{ }^{13} \mathrm{C}_{10}\right] \text { retinol from capsules }\end{array}$ & 0.03467 & $0.03108,0.03773$ & $0 \cdot 01415$ & $0.01126,0.01704$ \\
\hline & Mean & & 0.374 & & 0.377 \\
\hline & SD & & 0.059 & & 0.058 \\
\hline \multirow[t]{3}{*}{$\mathrm{A}_{\mathrm{C}, \text { cap }}$} & Dose $(\mu \mathrm{mol} / \mathrm{d})$ of $\left[{ }^{13} \mathrm{C}_{10}\right] \beta$-carotene from capsules & & & & \\
\hline & Mean & & 0.362 & & 0.361 \\
\hline & SD & & 0.058 & & 0.059 \\
\hline $\mathrm{AEq}, \mathrm{c}$ & Vitamin A equivalency $(\mu \mathrm{g})$ of $\left[{ }^{13} \mathrm{C}_{10}\right] \beta$-carotene in oil $\dagger$ & 3.7 & $2 \cdot 8,4 \cdot 6$ & $3 \cdot 6$ & $2 \cdot 9,4 \cdot 3$ \\
\hline
\end{tabular}

* The 'oil diet' contained vegetables low in $\beta$-carotene content supplemented with synthetic $\beta$-carotene in salad dressing oil and the 'mixed diet' contained vegetables high in $\beta$-carotene content. Each subject followed both diets for 2 weeks in a cross-over design. All 4 weeks, each subject daily consumed capsules with $\left[{ }^{13} \mathrm{C}_{10}\right] \beta$-carotene and $\left[{ }^{13} \mathrm{C}_{10}\right]$ retinol in oil.

$+\mathrm{AEq}_{\mathrm{C}}$ is the amount of $\beta$-carotene that has the same vitamin $A$ activity as $1 \mu \mathrm{g}$ retinol and was calculated by $1 /\left(\left(E_{5, \mathrm{sR}} / \mathrm{E}_{10, \mathrm{sC}}\right) \times\left(\mathrm{A}_{\mathrm{R}, \mathrm{cap}} \times 286 / \mathrm{A}_{\mathrm{C}, \mathrm{cap}} \times 537\right)\right)$.

added to the diet in oily capsules did not exchange with $\beta$-carotene in plant cells in the intestinal lumen. As a consequence, the assumption of this method, that labelled and unlabelled $\beta$-carotene fully mix, should be rejected. This isotopic technique cannot show that the dietary matrix affects the vitamin A equivalency of $\beta$-carotene; however, the oral-faecal balance technique does show that the dietary matrix affects the vitamin A equivalency of dietary $\beta$-carotene. This indicates that the extrinsic dual-isotope dilution technique (adding a tracer in oil capsules to the diet) with the current calculation is not suitable to investigate the absorption of $\beta$-carotene from plant matrices. Thus, the measured vitamin A equivalency of labelled $\beta$-carotene of 3.6:1 represented the highest feasible vitamin A equivalency, because the $\beta$-carotene was delivered to the intestine in the most optimal form, a solution in oil in a capsule, which dissolved in the stomach.

A preceding study with twenty-four healthy adults in The Netherlands showed a very similar vitamin A equivalency of $\beta$-carotene to retinol of $3 \cdot 4: 1^{(11)}$, which is comparable with the equivalency in the present study. This indicates that the vitamin A equivalency of $\beta$-carotene in healthy ileostomy subjects does not differ from that of healthy adults with an intact gastrointestinal tract.

Two other studies in Indonesian children ${ }^{(10,19)}$ with the same isotope technique showed vitamin A equivalencies of $\beta$-carotene to retinol of $2 \cdot 7: 1$ and $2 \cdot 4: 1$, respectively. These studies in a developing country were not diet-controlled, and the children did not have an optimal vitamin A status. Therefore, the present results are consistent with the expectation that the vitamin A equivalency of $\beta$-carotene could be lower in those with lower needs ${ }^{(1)}$.

In 2005, two studies were published that used intrinsic labelling of vegetables to quantify the vitamin A equivalency of $\beta$-carotene ${ }^{(20,21)}$. Novotny et al. ${ }^{(20)}$ produced complete ${ }^{13} \mathrm{C}$-labelled kale and calculated $28 \mathrm{~d}$ serum areas under the curve but did not estimate the vitamin A equivalency of $\beta$-carotene. Tang et al. ${ }^{(21)}$ produced two ${ }^{2} \mathrm{H}$-labelled

Table 5. Apparent absorption of total $\beta$-carotene (labelled and unlabelled) from $48 \mathrm{~h}$ after 2 weeks of controlled diets†

(Mean values and standard deviations)

\begin{tabular}{|c|c|c|c|c|c|}
\hline \multirow[b]{2}{*}{ Symbol } & \multirow[b]{2}{*}{ Description } & \multicolumn{2}{|c|}{ Oil diet $(n 17)$} & \multicolumn{2}{|c|}{ Mixed diet $(n 17)$} \\
\hline & & Mean & SD & Mean & SD \\
\hline \multirow{8}{*}{$\begin{array}{l}C_{f C} \\
W_{f} \\
A_{d} \\
A_{f} \\
A_{d}-A_{f} \\
A A_{C}\end{array}$} & Total $\beta$-carotene concentration in faeces $(\mu \mathrm{g} / \mathrm{g})$ & $2 \cdot 6$ & 0.9 & $7 \cdot 4^{*}$ & $2 \cdot 0$ \\
\hline & Weight of total faeces collection $(\mathrm{g} / 48 \mathrm{~h})$ & 1759 & 692 & 1809 & 735 \\
\hline & Dietary total $\beta$-carotene $(\mathrm{mg} / 48 \mathrm{~h})$ & $6 \cdot 1$ & 0.8 & $15 \cdot 2^{*}$ & $2 \cdot 9$ \\
\hline & Faecal $\beta$-carotene $(\mathrm{mg} / 48 \mathrm{~h})\left(\mathrm{C}_{\mathrm{fC}} \times \mathrm{W}_{\mathrm{f}}\right)$ & 4.3 & 1.3 & $12 \cdot 8^{*}$ & 3.9 \\
\hline & Apparent absorption of $\beta$-carotene $(\mathrm{mg} / 48 \mathrm{~h}) \ddagger$ & $1 \cdot 7$ & $1 \cdot 0$ & $2 \cdot 4^{\star}$ & $2 \cdot 9$ \\
\hline & Apparent absorption of $\beta$-carotene (\%)§ & & & & \\
\hline & Mean & \multirow{2}{*}{\multicolumn{2}{|c|}{$\begin{array}{c}29 \cdot 6 \\
23,37\end{array}$}} & \multicolumn{2}{|c|}{$15 \cdot 7^{*}$} \\
\hline & $95 \% \mathrm{Cl}$ & & & \multicolumn{2}{|c|}{6,24} \\
\hline
\end{tabular}

${ }^{*}$ Mean value was significantly different from that on the oil diet $(P<0.001$; paired $t$ test).

†The 'oil diet' contained vegetables low in $\beta$-carotene content supplemented with synthetic $\beta$-carotene in salad dressing oil and the 'mixed diet' contained vegetables high in $\beta$-carotene content. Each subject followed both diets for 2 weeks in a cross-over design. Daily for 4 weeks, each subject consumed capsules with labelled $\left[{ }^{13} \mathrm{C}_{10}\right] \beta$-carotene in oil.

$\ddagger$ Two subjects had a negative oral-faecal total $\beta$-carotene balance for the 'mixed diet'.

$\S A A_{C}$ was calculated by oral-faecal balance $(48 \mathrm{~h})$ as follows: $\left(A_{d}-A_{f}\right) / A_{d} \times 100$. 
vegetables and showed a vitamin A equivalency of $\beta$-carotene from spinach of 21:1 and of $\beta$-carotene from carrot of 15:1 calculated from $35 \mathrm{~d}$ serum areas under the curve, which are lower than we found. However, our isotope technique measured the plateau at 2 weeks after a diet with a mix of vegetables and fruits.

\section{Strengths and limitations of the extrinsic labelling technique}

The advantage of intrinsic labelling is that labelled $\beta$-carotene is contained within the food matrix instead of being added to or co-administered with food. However, intrinsic labelling has some significant limitations; these specially produced vegetables are very expensive, few subjects have been able to participate in the published studies and the vitamin A equivalency of $\beta$-carotene was determined after only a single meal. Furthermore, the vitamin A equivalency of $\beta$-carotene determined using intrinsic labelling might vary depending upon the plant and how it is prepared. Therefore, while the intrinsic labelling technique could provide reliable data for a few individuals eating a specific vegetable, it cannot provide data for a large population consuming a varied diet. Our extrinsic labelling technique can measure the vitamin A equivalency of the labelled $\beta$-carotene in oil capsules accurately but not the effect of dietary matrices.

\section{Estimated vitamin A equivalency of dietary $\beta$-carotene using data obtained with the oral-faecal balance technique}

Using data obtained with the oral-faecal balance technique, we observed that supplemental $\beta$-carotene in the 'oil diet' is an approximately 1.9 times better source of $\beta$-carotene (and thus vitamin A) than $\beta$-carotene in a 'mixed diet'. We cannot exclude the possibility that the lower apparent absorption in the 'mixed diet' is attributable to the higher absolute amount of $\beta$-carotene ingested. The 'oil diet' was representative of a diet high in $\beta$-carotene-poor vegetables and fruits with consumption of food items fortified with $\beta$-carotene and/or $\beta$-carotene supplements, such as regularly consumed in industrialised societies. The 'oil diet', which still contained about $15 \% \beta$-carotene from vegetables and fruits (Table 2), had an estimated vitamin A equivalency of $\beta$-carotene of $6 \cdot 7: 1$.

According to the current mixed-diet guideline of the US Institute of Medicine ${ }^{(3)}$, the vitamin A equivalency of $\beta$-carotene is $12: 1$, which is similar to our estimation for the 'mixed diet' (12.5:1). In the present study, the 'mixed diet' represented a healthy diet with amounts of cooked vegetables and fruits high in $\beta$-carotene content and including all necessary nutrients and fibres for optimal health.

When using the oral-faecal balance technique, the apparent absorption of $\beta$-carotene in healthy adults with an intact large bowel will probably always be overestimated because of bacterial degradation of $\beta$-carotene in the large bowel. The apparent absorption of $\beta$-carotene from both diets in these seventeen ileostomy subjects approaches apparent absorption of $\beta$-carotene in healthy adults, even with the shorter gastrointestinal transit time in the small intestine resulting from the surgical removal of the ileocaecal valve. Because of this fast transit, the collected ileostomy effluent over $48 \mathrm{~h}$ is representative for the dietary intake during this period, which is in contrast to adults with an intact gastrointestinal tract because of a variable residence time in the large bowel. Bacterial degradation in the ileostomy bag might still occur; however, the subjects were instructed to empty the bag into a box containing dry ice to optimise the integrity of $\beta$-carotene in the effluent.

Three studies have been published involving ileostomy subjects that all used mass balance over $24 \mathrm{~h}$ for measurement of apparent absorption of $\beta$-carotene. Faulks et al. ${ }^{(22)}$ showed an apparent absorption of $90 \%$ (range 74-97\%) in five ileostomy subjects after the consumption of ${ }^{13} \mathrm{C}$-labelled $\beta$-carotene in oil (dose $10 \mathrm{mg}$ ). Faulks et al. ${ }^{(23)}$ showed an apparent absorption of $\beta$-carotene of $25 \%$ (range $4-41 \%$ ) in seven ileostomy subjects after the consumption of spinach meals $(\beta$-carotene intake $10 \mathrm{mg})$. Livny et al. ${ }^{(24)}$ showed an apparent absorption of $\beta$-carotene of 65 (SD 7) \% from cooked carrot meals and $41 \%( \pm 7)$ from raw carrot meals in eight ileostomy subjects ( $\beta$-carotene intake $15 \mathrm{mg}$ ). In the present study, in which seventeen ileostomy subjects participated, the daily intake of $\beta$-carotene was either $3 \cdot 1$ or $7.6 \mathrm{mg}$, and ileostomy effluent collections were over $48 \mathrm{~h}$. Our data showed an apparent absorption of $\beta$-carotene of $30 \%$ (range $11-53 \%$ ) in the 'oil diet' and $16 \%$ (range $5-42 \%$ ) in the 'mixed diet'. In each study, the interindividual apparent absorption of $\beta$-carotene was highly variable. Nevertheless, these results indicate clearly that the vitamin A equivalency of $\beta$-carotene from various dietary matrices is dependent on the release of $\beta$-carotene from vegetable foods. A factor of 1.9 between the intestinal absorption of $\beta$-carotene dissolved in oil and $\beta$-carotene in vegetable foods appears to be realistic.

An earlier study of twenty-four healthy adults with similar diets showed a factor of 2.9 between apparent absorption of $\beta$-carotene in oil and $\beta$-carotene in vegetable foods ${ }^{(11)}$. The difference can be explained by intra-individual variation in faecal $\beta$-carotene and a much higher degree of bacterial degradation in the adults with an intact gastrointestinal tract.

\section{Serum $\beta$-carotene concentrations}

The serum $\beta$-carotene concentrations in these ileostomy subjects were three times lower than in the healthy adults in the previous study ${ }^{(11)}$. Also serum $\alpha$-carotene and serum $\beta$-cryptoxanthin concentrations in the ileostomy subjects were strikingly low. It should be noted that the serum retinol concentrations in these subjects were much greater than $1.07 \mu \mathrm{mol} / \mathrm{l}$, which excludes vitamin A deficiency.

An explanation of the low serum $\beta$-carotene concentrations at baseline in these ileostomy subjects could be the somewhat lower absorption of fat because of faster transit compared with subjects with an intact gastrointestinal tract and the relatively low consumption of vegetables and fruits because of the possibility of temporary blockage of the ileostomy. Based on the FFQ, which were completed before the present study to assess their daily habitual energy intake, these ileostomy subjects consume a mean of 2.7 servings of vegetables and 1.1 pieces of fruit. Their daily fibre consumption was $3.5 \mathrm{~g}$ lower than the habitual fibre consumption of the average Dutch adult (mean of 
18.1 v. $22.5 \mathrm{~g}$, taking into account the age group and sex ${ }^{(25)}$. During the present study, the subjects consumed about $28 \mathrm{~g}$ fibre (Table 2), and indeed, their serum $\beta$-carotene concentrations increased compared with baseline by consumption of more vegetable foods than their habitual intake. The influence of serum $\beta$-carotene concentrations (which also decrease with ageing) on the vitamin A equivalency of $\beta$-carotene should be assessed in future research.

\section{Conclusion}

Our oral-faecal balance data of seventeen healthy ileostomy subjects consuming a Western diet showed that the apparent absorption from supplemental $\beta$-carotene in oil was approximately 1.9 -fold higher than of $\beta$-carotene from vegetables and fruits. Our isotopic data showed that the vitamin $A$ equivalency of $\left[{ }^{13} \mathrm{C}_{10}\right] \beta$-carotene in oil was $3 \cdot 6: 1$ regardless of a high amount of unlabelled $\beta$-carotene either in an oil or vegetable matrix.

\section{Acknowledgements}

We kindly thank the volunteers who participated in the present study; Marjo Peters, Rianne Verhof, Ellen Geerards and Ellen Rasmussen of the Division of Dietetics for their advice and support; Marco Waals and all other kitchen staff members in the hospital for their cooperation; Pieter Versloot and Tineke van Roekel-Jansen of the Division of Human Nutrition for their help; Karin Bourgonjen, Janneke Dopheide, Celine Brattinga, Marlies Regelink and Lillian van Nispen for their assistance during the intervention study; and all other individuals who contributed to this research. The present study was conducted under ClinicalTrials.gov identifier NCT00128804. The present study was financially supported by the Dutch Dairy Association.

C. A. vL.-B., T. H. J. N. and C. E. W. designed the study and H. D., E. S., P. J. M. H., F. G. M. R., and G. S. provided significant advice and consultation. R. B. vB. and D. Z. performed the enrichment analyses and P. J. M. H. was responsible for the carotenoid analyses. H. D. and E. S. coordinated the preparation and distribution of the diets. C. A. vL.-B. was in charge of the data collection and analysed the data. T. H. J. N., F. G. M. R., and G. S. assisted with the calculations. C. A. v L.-B. wrote the manuscript and all authors, except C. E. W. (deceased), provided a critical review of the manuscript.

None of the authors had a personal or financial conflict of interest.

\section{References}

1. Food and Agriculture Organization \& World Health Organization (1988) Requirements of Vitamin A, Iron, Folate and Vitamin $B_{12}$. Report of a FAO/WHO Joint Expert Consultation. FAO Food and Nutrition Series 23. Rome: FAO.

2. Food and Agriculture Organization \& World Health Organization (2004) Vitamin and Mineral Requirements in Human Nutrition, 2nd ed. FAO/WHO Joint Expert Consultation. Geneva: WHO Press.

3. Institute of Medicine (2001) Dietary Reference Intakes for Vitamin A, Vitamin K, Arsenic, Boron, Chromium, Copper, Iodine, Iron, Manganese, Molybdenum, Nickel, Silicon,
Vanadium, and Zinc. Washington, DC: National Academy Press.

4. van Lieshout $M$, West CE \& van Breemen RB (2003) Isotopic tracer techniques for studying the bioavailability and bioefficacy of dietary carotenoids, particularly $\beta$-carotene, in humans: a review. Am J Clin Nutr 77, 12-28.

5. Burri BJ \& Clifford AJ (2004) Carotenoid and retinoid metabolism: insights from isotope studies. Arch Biochem Biophys 430, 110-119.

6. Wang Z, Yin S, Zhoa X, et al. (2004) $\beta$-Carotene-vitamin A equivalency in Chinese adults assessed by a isotope dilution technique. Br J Nutr 91, 121-131.

7. Tang G, Qin J, Dolnikowski GG, et al. (2003) Short-term (intestinal) and long-term (postintestinal) conversion of $\beta$-carotene to retinol in adults as assessed by a stable-isotope reference method. Am J Clin Nutr 78, 259-266.

8. You C-S, Parker RS \& Swanson JE (2002) Bioavailability and vitamin A value of carotenes from red palm oil assessed by an extrinsic isotope reference method. Asia Pacific J Clin Nutr 11, S438-S442.

9. Edwards AJ, Nguyen CH, You C-S, et al. (2002) $\alpha$ - and $\beta$-Carotene from a commercial carrot purée are more bioavailable to humans than from boiled-mashed carrots, as determined using an extrinsic stable isotope reference method. J Nutr 132, 159-167.

10. van Lieshout M, West CE, Muhilal, et al. (2001) Bioefficacy of $\beta$-carotene dissolved in oil studied in children in Indonesia. Am J Clin Nutr 73, 949-958.

11. Van Loo-Bouwman CA, West CE, van Breemen RB, et al. (2009) Vitamin A equivalency of $\beta$-carotene in healthy adults; limitation of the extrinsic dual-isotope dilution technique to measure matrix effect. $B r \quad J$ Nutr 101, 1837-1845.

12. Feunekes GI, van Staveren WA, de Vries JH, et al. (1993) Relative and biomarker-based validity of a food-frequency questionnaire estimating intake of fats and cholesterol. Am J Clin Nutr 58, 489-496.

13. NEVO Foundation Bureau (2001) Dutch Food Database 2001. The Hague: Dutch Nutrition Centre.

14. Health Council of the Netherlands (2006) publication no. 2006/ 21Guidelines for a Healthy Diet. The Hague: Health Council of the Netherlands.

15. Lugtenburg J, Creemers AFL, Verhoeven MA, et al. (1999) Synthesis of ${ }^{13} \mathrm{C}$ labeled carotenoids and retinoids. Pure Appl Chem 71, 2245-2251.

16. van Breemen RB, Nikolic D, Xu X, et al. (1998) Development of a method for quantification of retinol and retinyl palmitate in human serum using high-performance liquid chromatography-atmospheric pressure chemical ionizationmass spectrometry. J Chromatogr A 794, 245-251.

17. Zhu D, Wang Y, Pang Y, et al. (2006) Quantitative analyses of $\beta$-carotene and retinol in serum and feces in support of clinical bioavailability studies. Rapid Commun Mass Spectrom 20, 2427-2432.

18. Wang Y, Xu X, van Lieshout M, et al. (2000) A liquid chromatography-mass spectrometry method for the quantification of bioavailability and bioconversion of $\beta$-carotene in humans. Anal Chem 72, 4999-5003.

19. van Lieshout M, West CE \& Wang Y, et al. (2001) Bioavailability and bioefficacy of $\beta$-carotene measured using $\beta$-carotene and retinol, labeled with ${ }^{13} \mathrm{C}$, in Indonesian children. In van Lieshout M. Bioavailability and bioefficacy of $\beta$-carotene measured using ${ }^{13} \mathrm{C}$-labeled $\beta$-carotene and retinol: studies in Indonesian children. $\mathrm{PhD}$ thesis. Wageningen University.

20. Novotny JA, Kurilich AC, Britz SJ, et al. (2005) Plasma appearance of labeled $\beta$-carotene, lutein, and retinol in humans after 
consumption of isotopically labeled kale. J Lipid Res $\mathbf{4 6}$, 1896-1903.

21. Tang G, Qin J, Dolnikowski GG, et al. (2005) Spinach or carrots can supply significant amounts of vitamin A as assessed by feeding with intrinsically deuterated vegetables. Am J Clin Nutr 82, 821-828.

22. Faulks RM, Hart DJ, Wilson PDG, et al. (1997) Absorption of all-trans and 9-cis $\beta$-carotene in human ileostomy volunteers. Clin Sci 93, 585-591.
23. Faulks RM, Hart DJ, Brett GM, et al. (2004) Kinetics of gastro-intestinal transit and carotenoid absorption and disposal in ileostomy volunteers fed spinach meals. Eur J Nutr 43, $15-22$.

24. Livny O, Reifen R, Levy I, et al. (2003) $\beta$-Carotene bioavailability from differently processed carrot meals in human ileostomy volunteers. Eur J Nutr 42, 338-345.

25. Dutch Nutrition Centre (1998) Results of the Food Consumption Measurement 1997-1998. The Hague: Dutch Nutrition Centre. 